\title{
A contribution to the design of powered roof support for operations in a rockburst-hazardous environment
}

\begin{abstract}
The paper presents an example of a numerical analysis using ANSYS to optimise the design of powered roof support designed to operate in rock mass tremor hazard conditions. The areas of excessive stress in the structure of powered roof support were identified, taking into account the increase in rock mass loading resulting from tremors. An increase in the load impacting on the support as a result of rock mass tremors is the cause of excessive stresses in the section structure. The paper aims to identify them and to find ways to apply the design using numerical analysis. The analysis was conducted for roof support type ZRP-15/35-POz produced in Repair and Production Plant (ZRP-Bierun) of Polish Mining Group S.A. (PGG S.A.) The introduction of reinforcements in places of increased stress in the support section structure should increase its operational safety in the excavation.
\end{abstract}

Key words: powered roof support, numerical modelling, rock mass tremors, dynamic loads

\section{INTRODUCTION}

Powered roof support is part of the basic equipment of a longwall system and is responsible, among other things, for securing the workings against roof rockfall into the working space. The high variability of geological-mining conditions, including those resulting from natural hazards, in particular rock mass tremors, places high support requirements on lining sections. These requirements include both static and dynamic loads [1, 2]. Longwall powered roof supports are marketed following the regulations laid down in the Directives and Polish standards harmonised with them. The basic directive is the Machinery Directive [3] and Polish standards harmonised with it from the PN-EN 1804 series [4-6]. The scope of safety requirements laid down in harmonised standards does not cover the case of rock mass tremor hazards. The safety requirements for rock mass tremor hazard conditions are supplemented following the Regulation of the Minister of Energy of 23 November 2016, Journal of Laws. No. 2017 item $1118 \S 523$ paragraph 1, pt. 1, and concerns yielding [7]. The provision does not specify in detail the requirements and procedures to be followed, leaving the problem to the discretion of the scientific research unit preparing the evaluation of the yielding of the support. Figure 1 shows an example of the rules for the introduction of powered roof support intended for work in rock mass tremor hazard conditions into the market and service, based on the directives and harmonised Polish standards.

Currently, the yielding assessment is prepared by the Central Mining Institute (GIG) according to its methodology. The GIG methodology assumes that due to a rock mass tremor, the hydraulic leg of the support must not be overloaded beyond the permissible capacity, taking into account its overload factor [8-12]. Safety was related to the leg assuming that it is the most important element supporting the roof. Such assumptions allow for the overloading of individual support elements beyond their capacity. 


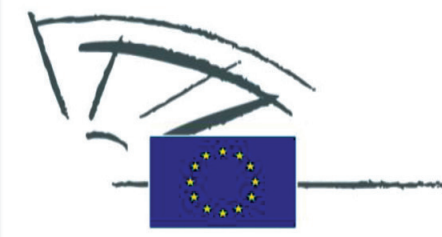

European Parliament Directives

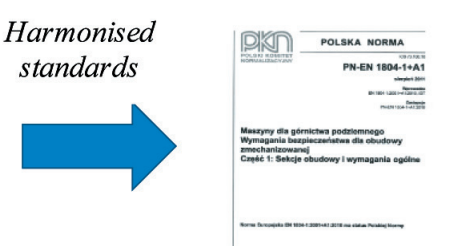

PN-EN 1804-1+A1:2011
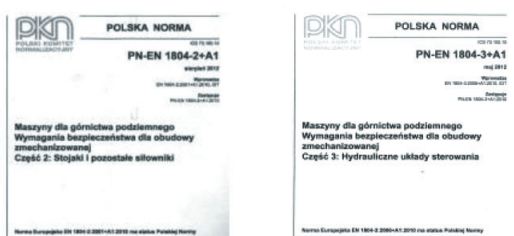

PN-EN 1804-2+A1:2012

Chapter 2,

Powered roof supports and mining machines

\$523.

Obudowę zmechanizowang przeznaczong do pracy w:

1) scianach prowadzonych w rejonach występowania wstrzasow gorotworu - przystosowuje się przez upodatnienie do przejmowania obcigten

dynamicznych;

Fig. 1. Principles of introducing powered roof support intended for operation in rock mass tremor hazard conditions into the Polish market and exploitation

The paper aims to determine the locations in the support structure where stresses exceed the permissible values for increased strength loads on the support using numerical modelling, which has been successfully used in other fields of science such as aviation, construction, or the automotive industry [13-15].

For the cases analysed, an increased support load of $100 \%$ over the working values was assumed, while the method of support loading was referred to in the PN-EN1804-1+A1:2011 standard. Areas, where the stress in the material of the support exceeds the permissible limits, should be redesigned or reinforced for safety. Numerical methods using ANSYS [16] were used to analyse the stresses in the support elements for different support modes and overload values. The subject of the analysis is a powered roof support type ZRP-15/35-POz. The results, in the form of stress maps, will be used by designers when upgrading the support, as well as in the development of the support yielding evaluation.

\section{THE SUBJECT OF THE ANALYSIS - A POWERED ROOF SUPPORT TYPE ZRP-15/35-POZ}

The ZRP-15/35-POz powered roof support was developed in the design office of Repair and Production Plant - ZRP Bierun (ZRP) and is manufactured by $Z R P$, as well as by other companies commissioned by Polish Mining Group S.A. (PGG S.A.) The documentation is supplemented by $2 \mathrm{D}$ support drawings made using CAD software, which can be used for fur- ther numerical analysis. An overview drawing of the support and the basic technical parameters are shown below in Figure 2.

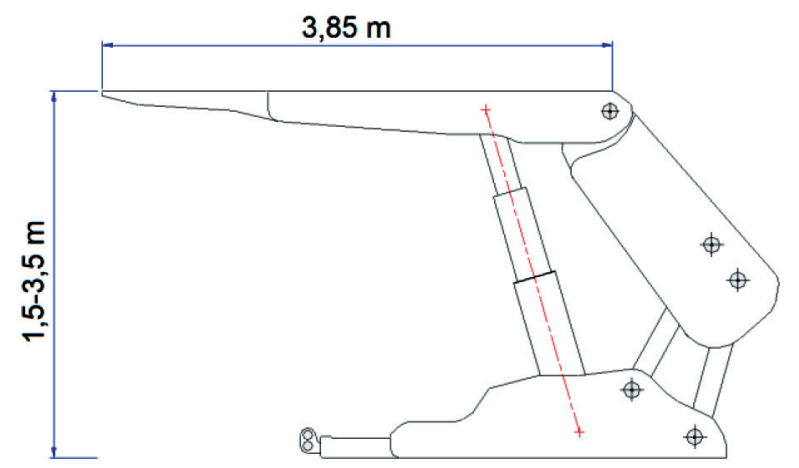

\begin{tabular}{|l|l|}
\hline \multicolumn{2}{|c|}{ Geometric and support data } \\
\hline $\begin{array}{l}\text { Geometric/ lateral range of } \\
\text { support height }\end{array}$ & $1.5-3.5 \mathrm{~m} / 1.7-3.4 \mathrm{~m}$ \\
\hline Sectional steps & $0.8 \mathrm{~m}$ \\
\hline Length of the canopy & $3.85 \mathrm{~m}$ \\
\hline Type & $\begin{array}{l}\text { shield support equipped with } \\
\text { two legs }\end{array}$ \\
\hline Number of legs & 2 \\
\hline I / II diameters of the legs & $\varnothing 0.30 / 0.23 \mathrm{~m}$ \\
\hline Initial leg support & $1.767-2.121 \mathrm{MN}$ \\
\hline Working leg support & $3.039 \mathrm{MN}$ \\
\hline Supply pressure & $25-30 \mathrm{MPa}$ \\
\hline Working pressure & $43 \mathrm{MPa}$ \\
\hline Leg securing system & type ZRP II \\
\hline
\end{tabular}

Fig. 2. Outline drawing and basic technical data of powered roof support type ZRP-15/35-POz

The designed section ZRP-15/35-POz is included in the current program of the ZRP plant connected with the unification and standardization of powered supports for the needs of PGG S.A. 


\section{PREPARATION OF THE MODEL AND ITS BORDER CONDITIONS}

Using drawings imported from $\mathrm{CAD}$, a 3D model was built to represent the structural form of the powered roof support in terms of the geometry of the entire system. Figure 3 shows the created 3D model of the ZRP-15/35-POz powered roof support used for further analysis.

The kinetostatic calculations of the model were performed with the PrsLab 1.4.5 program [17] while the strength calculations were performed with the ANSYS program [16]. Isotropic material with linear deformation characteristics was assumed for the analyses. The material parameters were taken as for structural steel, i.e. Young's modulus $E=200 \mathrm{GPa}$ and Poisson's ratio $v=0.3$. The minimum yield point of steel grade $\mathrm{S} 690 \mathrm{QL}$ was used as the strength criterion, i.e. $R e=690 \mathrm{MPa}$. The mesh and number of elements were generated by ANSYS software. Numerical calculations were performed for loads of the support ele-

a)
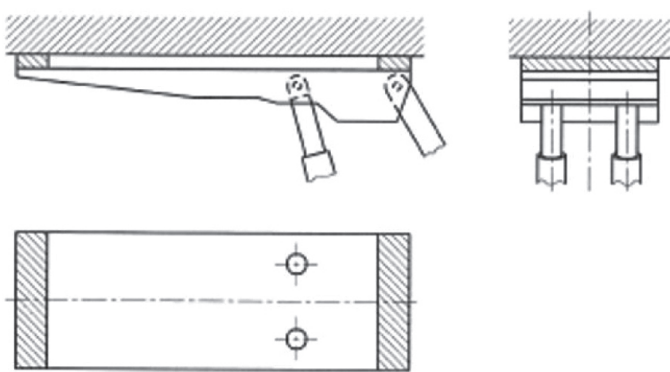

b)
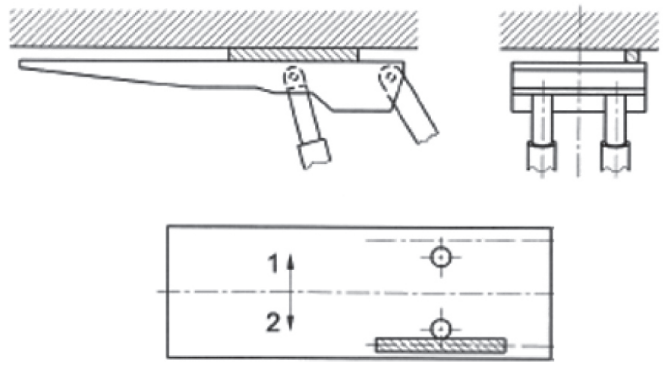

c)
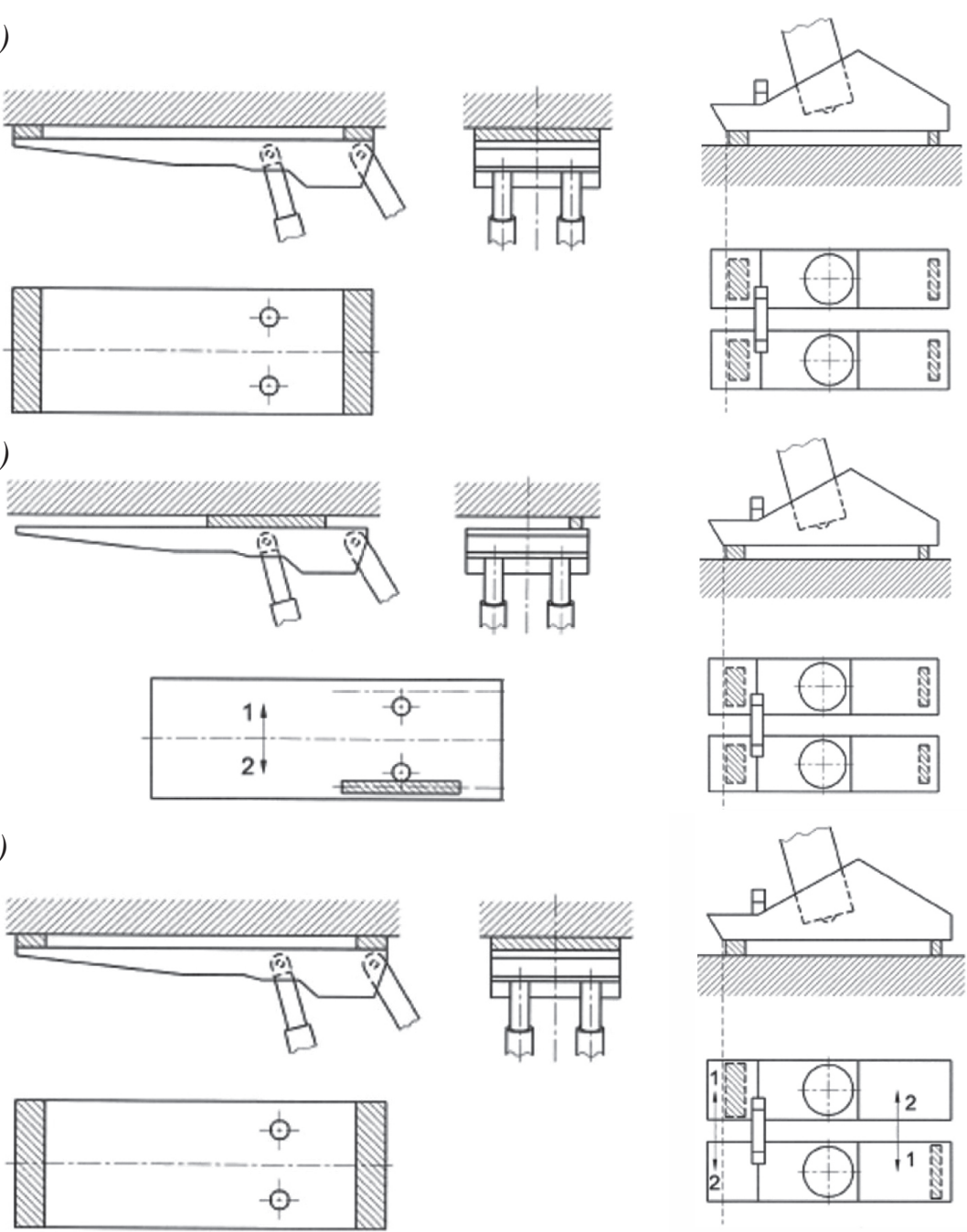

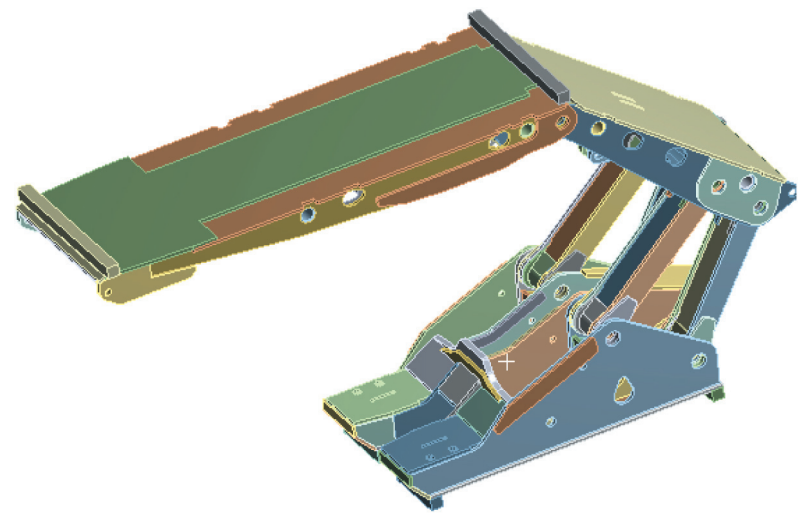

Fig. 3. A spatial model of powered roof support

ZRP-15/35-POz used in numerical calculations

ments following PN-EN 1804-1+A1:2011 [4] and assumed overload coefficients of 1.05 for asymmetrical loads, and 1.2 for symmetrical loads. Additionally, for symmetrical and asymmetrical loads, an overload factor of 2.0 was adopted according to the GIG method for the yielding of powered roof support [11,12]. The subject of analysis was supported as shown in Figure 4.
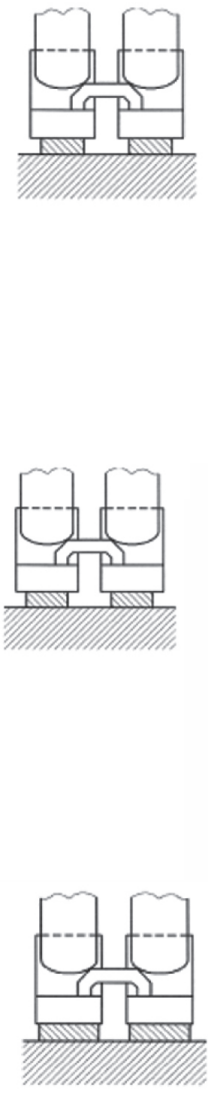

Fig. 4. Analysed ways of supporting sections: a) symmetry; b) asymmetry of the side of the canopy; c) asymmetry on the diagonal of the floor base 
The numerical analysis was carried out for the three selected ways of support and for the working height of the ZRP powered roof support for which the highest stresses in the material of the elements occur.

\section{NUMERICAL CALCULATION OF POWERED ROOF SUPPORTS}

The results of the numerical simulations carried out are presented in the form of colour maps of the stresses reduced in the individual elements of the powered roof support. The simulations were carried out separately for the basic elements of the support (canopy, caving shield, base) and jointly for the roof support. The publication only presents maps of reduced stresses that sufficiently represent the results of the numerical analyses carried out. The analyses were carried out for overload values resulting from the Polish standard for different ways of supporting the roof support (1.05 and 1.2) and for the case of overload resulting from the yielding condition (2.0), as a derivative of the rock mass tremor. Maps of the reduced stresses in the roof support and their components for different support modes and overload factors are shown in Figures 5-10.

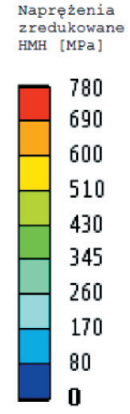

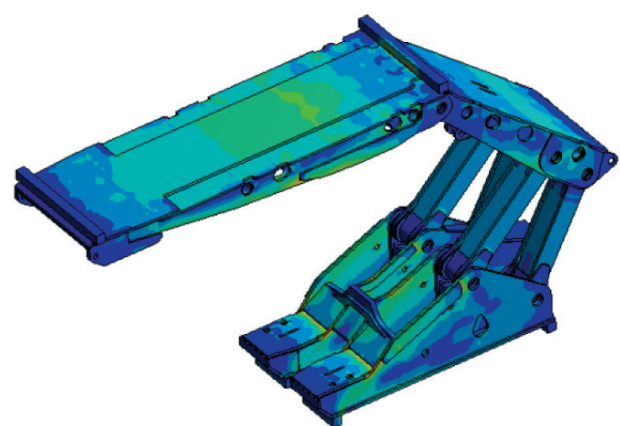

Overload factor 1,2

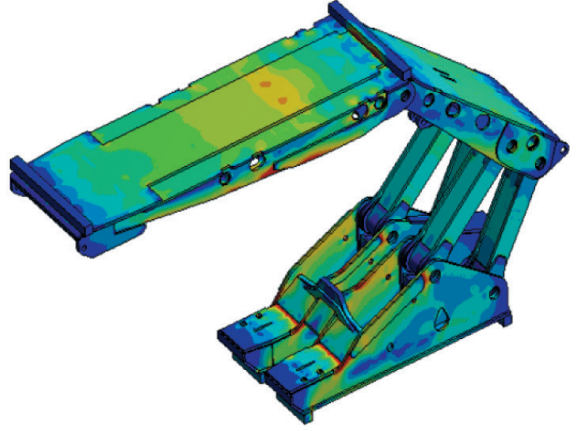

Overload factor 2,0

Fig. 5. Maps of reduced stresses in the section with symmetric support according to Figure $4 a$

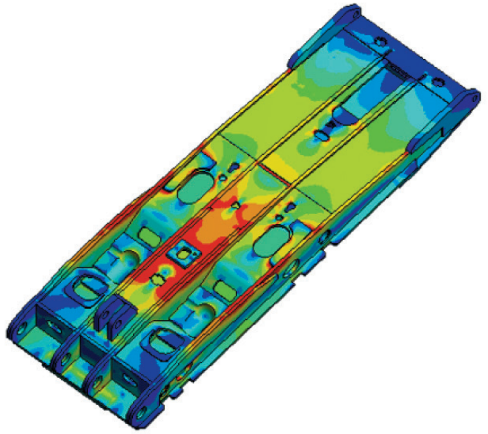

canopy

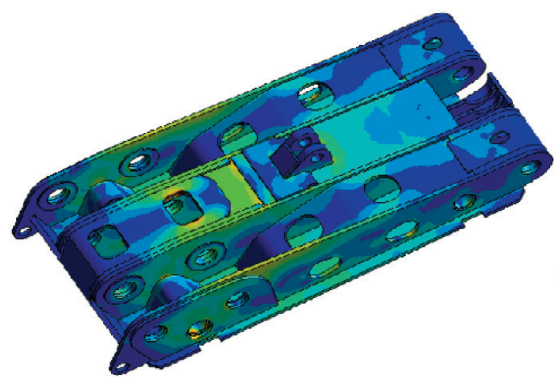

caving shield

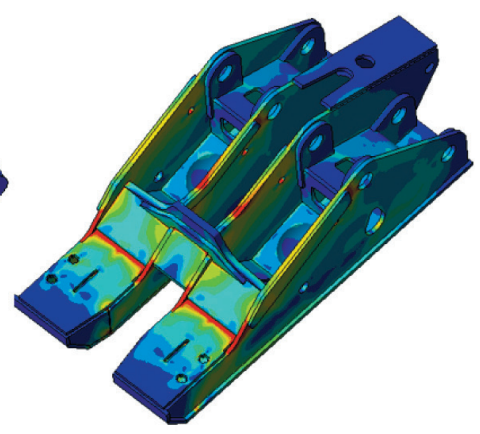

base

Overload factor 2,0

Fig. 6. Maps of reduced stresses in elements of sections with symmetric support according to Figure $4 a$
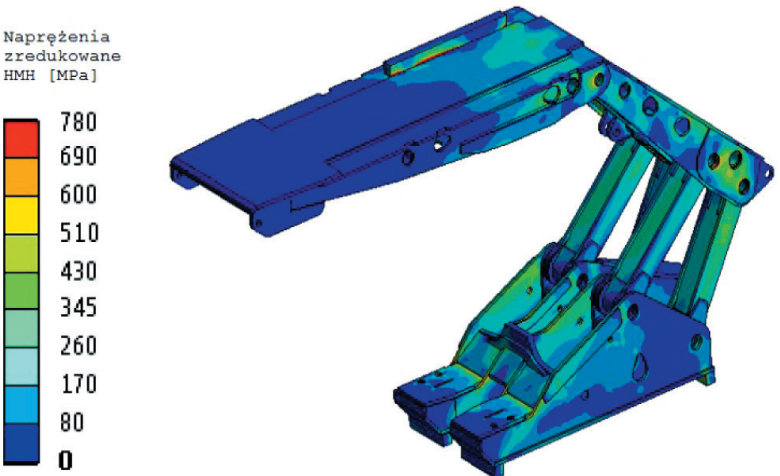

Overload factor 1,05

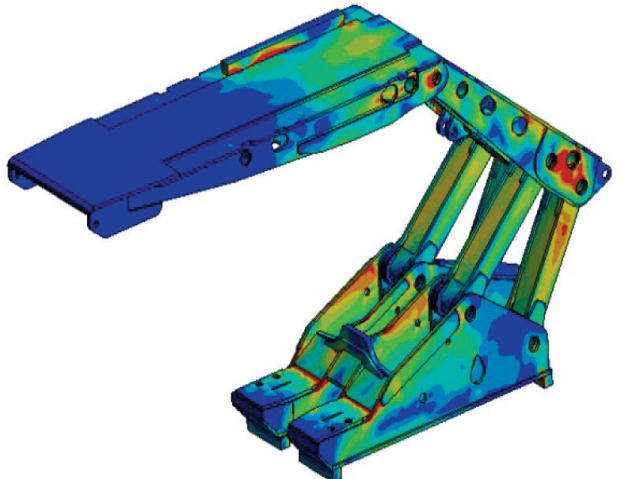

Overload factor 2,0

Fig. 7. Maps of reduced stresses in the section with asymmetric canopy support according to Figure $4 b$ 


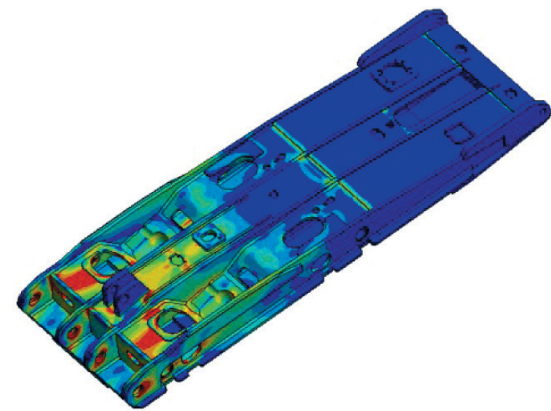

canopy

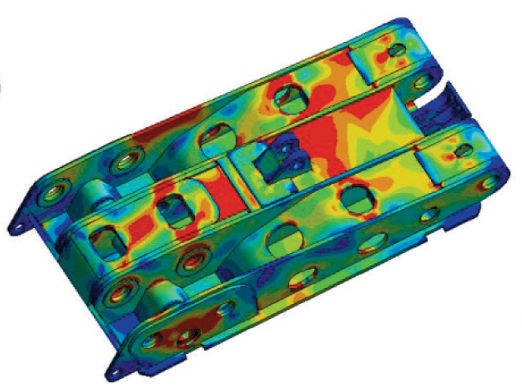

caving shield

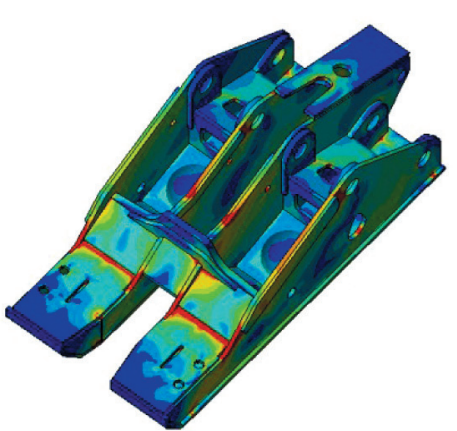

base

Overload factor 2,0

Fig. 8. Maps of reduced stresses in section elements with asymmetric canopy support according to Figure $4 b$

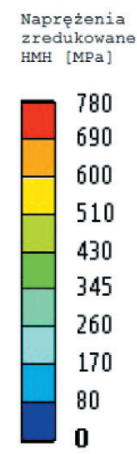

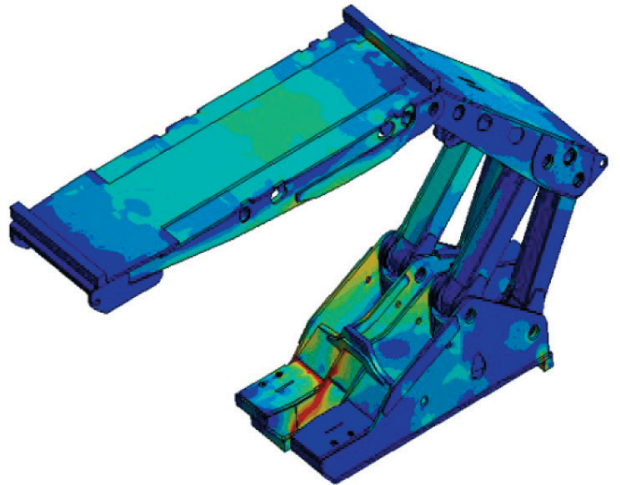

Overload factor 1,05

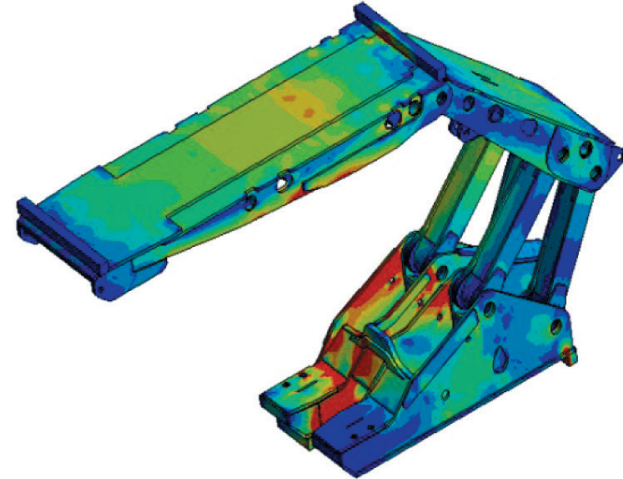

Overload factor 2,0

Fig. 9. Reduced stress maps in the section with diagonal asymmetry of the floor base according to Figure $4 c$

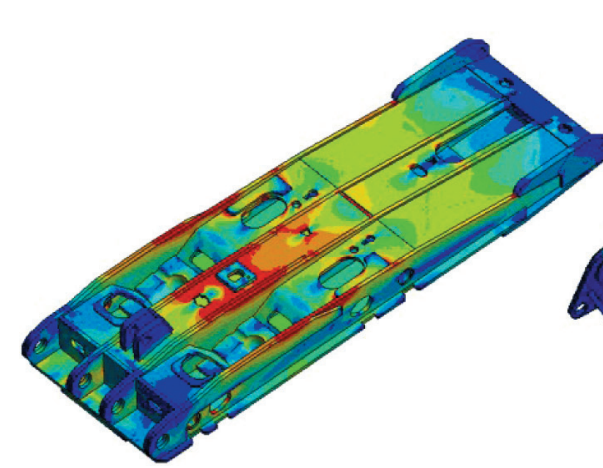

canopy

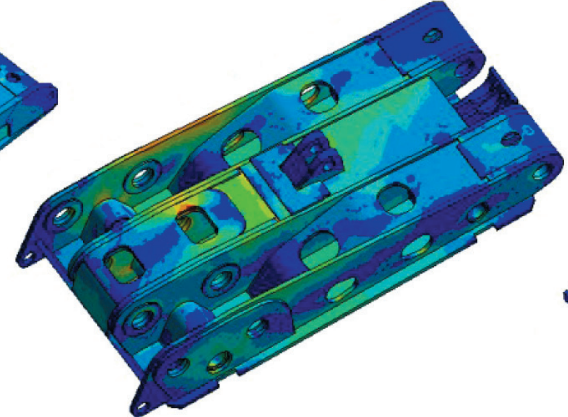

caving shield

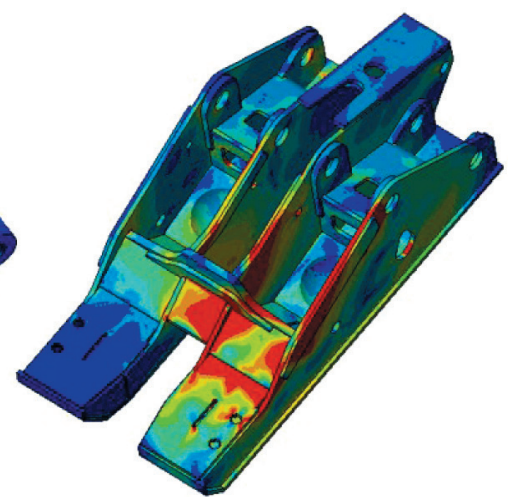

base

Overload factor 2,0

Fig. 10. Maps of reduced stresses in elements of sections with diagonal asymmetry of the floor base according to Figure $4 c$

\section{SUMMARY AND I CONCLUSION}

The problem presented in this article concerns an extremely important issue for the safety of longwall exploitation since currently more than $60 \%$ of extraction takes place in seams exposed to rock mass tremors. The occurrence of rock mass tremors results in overloading the powered roof support structure significantly above the coefficients $(1.05$ and 1.2$)$ required by Polish standards $[2,5,6,11]$. There is also the possibility of a large asymmetry in the load distribution on the roof support which further deteriorates the operating conditions of the section. This is why the authors of the publication decided to load the 
roof support with twice the overload to get an indication of the extent and location in the structure of the occurrence of increased overloads (marked in red in Figures 5-10). As shown in Figure 6, under symmetrical loading the largest overloads occur at the canopy of the section. In the case of asymmetric roof support, the highest overloads occur in the shield support Figure 8. In the case of diagonal asymmetry of the floor base, the most overloaded elements are the elements of the base and the canopy, as shown in Figure 10.

The data obtained regarding the overloading of individual elements of the roof support allows the designer to strengthen these areas by changing the strength of the material, reinforcing them, or making structural changes. Each such action improves occupational safety and extends the failure-free operation of the powered roof support. The numerical analyses carried out also indicate that it is advisable to carry out numerical calculations of the section's structure given the large discrepancies between the overload coefficients required by Polish standards and the overloads occurring. The presented procedure will be implemented in the process of designing and manufacturing sections at ZRP-Bieruń.

\section{References}

[1] Prusek S., Rajwa S., Wrana A., Krzemień A.: Assessment of roof fall risk in longwall coal mines, "International Journal of Mining, Reclamation and Environment" 2016: 1-17.

[2] Świątek J., Stoiński K.: Case Analysis of Damages to Control Hydraulics of the Leg in the Powered Roof Support Section, IV $^{\text {th }}$ International Innovative Mining Symposium, E3S Web Conf. Vol. 105, 2019, DOI: https://doi.org/10.1051/e3sconf/ 201910503013

[3] Dyrektywa 2006/42/WE Parlamentu Europejskiego i Rady $z$ dnia 17 maja $2006 r$. w sprawie maszyn, zmieniajaca dyrektywę 95/16/WE, Dziennik Urzędowy Unii Europejskiej L157/24.

[4] PN-EN 1804-1+A1:2011: Maszyny dla górnictwa podziemnego - Wymagania bezpieczeństwa dla obudowy zmechanizowanej-Częśc 1: Sekcje obudowy i wymagania ogólne.
[5] PN-EN 1804-2+A1:2012: Maszyny dla górnictwa podziemnego - Wymagania bezpieczeństwa dla obudowy zmechanizowanej-Część 2: Stojaki i pozostałe siłowniki.

[6] PN-EN 1804-3+A1:2012: Maszyny dla górnictwa podziemnego - Wymagania bezpieczeństwa dla obudowy zmechanizowanej-Część 3: Hydrauliczne układy sterowania.

[7] Rozporządzenie Ministra Energii z dnia 23 listopada 2016 r. w sprawie szczegółowych wymagań dotyczacych prowadzenia ruchu podziemnych zakładów górniczych, Dz.U. z 2017 r., poz. 1118.

[8] Prusek S., Rajwa S., Walentek A., Masny W.: Powered support selection for longwall workings in dynamic load conditions, "3rd International Symposium on Mine Safety Science and Engineering, Montreal” 2016: 13-19.

[9] Rajwa S., Masny W., Wrana A.: A comprehensive method for the selection of powered roof support in conditions of the rockburst hazard, "Wiadomości Górnicze" 2017, 1: 2-7.

[10] Rajwa S., Prusek S., Stoiński K.: Opis metody upodatnienia zmechanizowanej obudowy ścianowej, "Bezpieczeństwo Pracy i Ochrona Środowiska w Górnictwie" 2016, 12: 3-8.

[11] Stoiński K.: Obudowy górnicze $w$ warunkach zagrożenia wstrzasami górotworu, Wydawnictwo GIG, Katowice 2000.

[12] Stoiński K.: Metoda upodatnienia sekcji zmechanizowanych obudów ścianowych, Praca statutowa GIG, No. 10001103-150, Katowice 2006 [unpublished].

[13] Przemyk A., Harlecki A., Tengler S.: Metoda obliczania wytrzymałości ram samochodów ciężarowych, "Autobusy" 2017, 12: $1252-1257$.

[14] Dębski H., Koszałka G., Ferdynus M.: Wykorzystanie MES $w$ analizie struktury nośnej ramy naczepy o zmiennych parametrach eksploatacyjnych, "Eksploatacja i Niezawodność" 2012, 14, 2: 107-113.

[15] Osmęda A.: Porównanie wyników analiz numerycznych i prób wytrzymałościowych demonstratora struktury lotniczej, "Prace Instytutu Lotnictwa" 2016, 3, 244: 123-134.

[16] ANSYS V16, 2015.

[17] PrsLab 1.4.5, program of PGG S.A., Oddział ZRP.

JANINA ŚWIATTEK, Ph.D., Eng. KAZIMIERZ STOIŃSKI, prof.

Główny Instytut Górnictwa (The Central Mining Institute) pl. Gwarków 1, 40-166 Katowice, Poland \{jswiatek, kstoinski\}@gig.eu KONRAD STYRYLSKI, M.Sc., Eng. PGG S.A. Zakład Remontowo-Produkcyjny ul. Granitowa 132, 43-155 Bieruń, Poland konrad.styrylski@gmail.com

(C) 2020 Authors. This is an open access publication, which can be used, distributed and reproduced in any medium according to the Creative Commons CC-BY 4.0 License. 


\title{
Przyczynek do projektowania konstrukcji sekcji zmechanizowanej obudowy ścianowej przeznaczonej do pracy w warunkach zagrożenia wstrząsami górotworu
}

\begin{abstract}
Przedstawiono przykład analizy numerycznej z wykorzystaniem programu ANSYS dotyczacej optymalizacji konstrukcji sekcji zmechanizowanej obudowy ścianowej, przeznaczonej do pracy w warunkach zagrożenia wstrząsami górotworu. Uwzględniając wzrost obciązenia obudowy ze strony górotworu wynikający z występowania wstrząsów, określono miejsca występowania nadmiernych naprężeń $w$ konstrukcji sekcji zmechanizowanej obudowy ścianowej. Wzrost obciążenia obudowy jako następstwo wstrzasów górotworu jest przyczyna występowania nadmiernych naprężeń $w$ konstrukcji sekcji. Ich identyfikacja oraz uwzględnienie $w$ projektowaniu $z$ wykorzystaniem analizy numerycznej przedstawia niniejszy artykut. Analize przeprowadzono dla obudowy typu ZRP-15/35-POz produkowanej w Zaktadzie Remontowo-Produkcyjnym (ZRP-Bieruń) Polskiej Grupy Górniczej S.A. Wprowadzenie wzmocnień w miejscach występowania zwiększonych naprężeń konstrukcji sekcji obudowy powinno zwiększyć jej bezpieczeństwo pracy w wyrobisku.
\end{abstract}

Słowa kluczowe: obudowa zmechanizowana, modelowanie numeryczne, wstrzasy górotworu, obcią̇enia dynamiczne

\section{WPROWADZENIE}

Zmechanizowana obudowa ścianowa należy do podstawowego wyposażenia kompleksu ścianowego i odpowiedzialna jest między innymi za zabezpieczenie wyrobiska przed opadem skał stropowych do jego przestrzeni roboczej. Duża zmienność warunków geologiczno-górniczych, w tym wynikająca z zagrożeń naturalnych, w szczególności wstrząsami górotworu, stawia wysokie wymagania podpornościowe wobec sekcji obudowy. Wymagania te zawierają się zarówno w zakresie obciążeń statycznych, jak również dynamicznych $[1,2]$. Sekcje zmechanizowanej obudowy ścianowej są wprowadzane na rynek zgodnie $\mathrm{z}$ uregulowaniami ujętymi dyrektywami oraz ze zharmonizowanymi z nimi polskimi normami. Podstawową dyrektywą jest dyrektywa maszynowa [3] oraz polskie normy z nią zharmonizowane z serii PN-EN 1804 [4-6]. Zakres wymagań bezpieczeństwa określony w zharmonizowanych normach nie obejmuje przypadku zagrożenia wstrząsami górotworu. Uzupełnienie wymagań bezpieczeństwa dla warunków zagrożenia wstrząsami górotworu następuje zgodnie z Rozporzą- dzeniem Ministra Energii z dnia 23 listopada 2016 r. (Dz.U. Nr 2017 poz. 1118 §523 ust. 1, pkt 1), dotyczącym upodatnienia [7]. Zapis nie określa szczegółowo wymagań i procedur postępowania, pozostawiając problem w gestii jednostki naukowo-badawczej opracowującej opinię dotyczącą upodatnienia sekcji obudowy. Na rysunku 1 przedstawiono, opierając się na dyrektywach i zharmonizowanych polskich normach, zasady wprowadzania na rynek i do eksploatacji sekcji zmechanizowanych obudów ścianowych przeznaczonych do pracy w warunkach zagrożenia wstrząsami górotworu.

Aktualnie ocenę upodatnienia opracowuje Główny Instytut Górnictwa (GIG) według metodyki własnej. Metodyka GIG zakłada, że wskutek wstrząsu górotworu dla poszczególnych ocenianych przypadków nie może nastąpić przeciążenie stojaka hydraulicznego sekcji ponad dopuszczalną podporność, przy uwzględnieniu współczynnika jego przeciążenia [8-12]. Bezpieczeństwo odniesiono do stojaka sekcji, zakładając, że jest najważniejszym elementem podpierającym strop. Przyjęcie takich założeń dopuszcza wystąpienie przeciążeń poszczególnych elementów sekcji ponad ich wytrzymałość. 


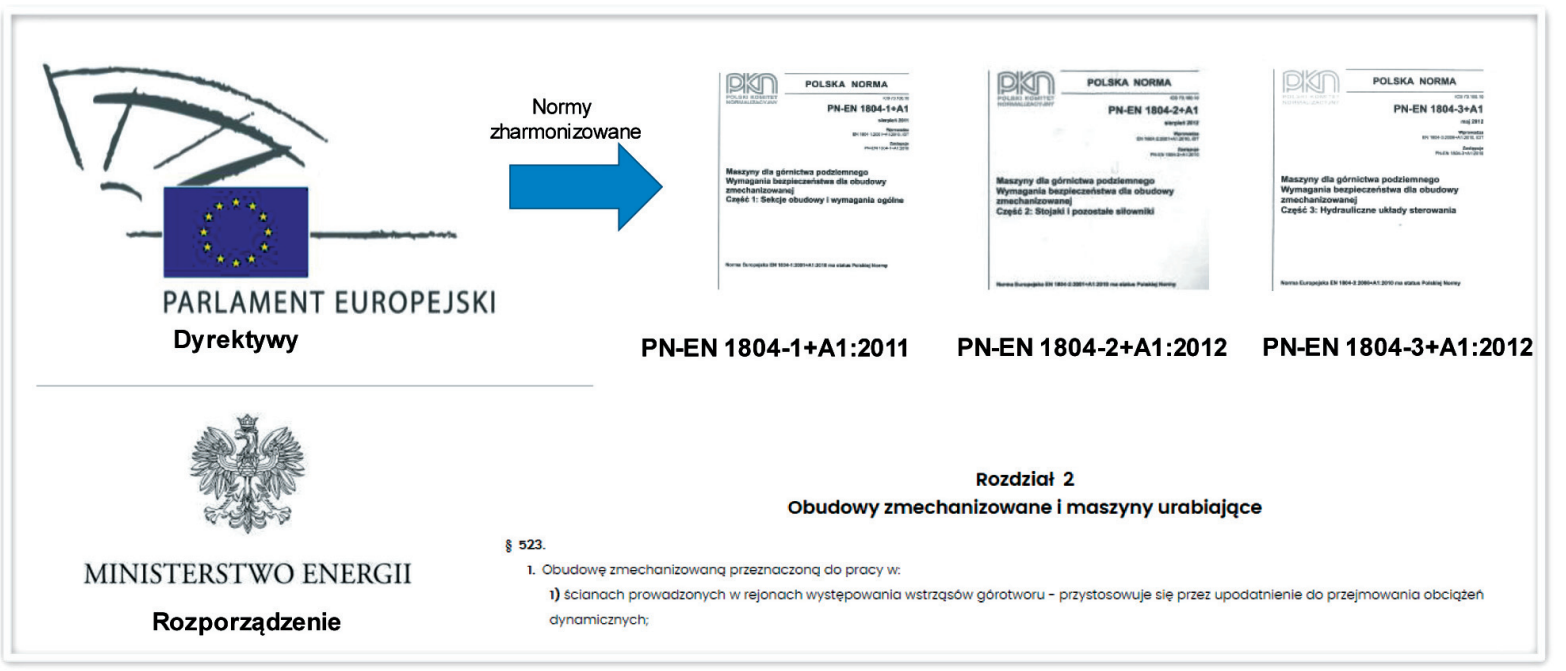

Rys. 1. Zasady wprowadzania na polski rynek i do eksploatacji zmechanizowanych obudów ścianowych przeznaczonych do pracy $w$ warunkach zagrożenia wstrząami górotworu

Niniejsza praca ma na celu wyznaczenie miejsc w konstrukcji sekcji, w których występują naprężenia przekraczające wartości dopuszczalne dla zwiększonych obciążeń wytrzymałościowych sekcji przy wykorzystaniu modelowania numerycznego, które z powodzeniem jest stosowane w innych dziedzinach nauki, takich jak lotnictwo, budownictwo czy przemysł samochodowy [13-15].

Dla analizowanych przypadków przyjęto zwiększone obciążenie sekcji o $100 \%$ ponad wartości robocze, natomiast sposób obciążenia sekcji odniesiono do ujętego normą PN-EN1804-1+A1:2011. Miejsca, w których naprężenia w materiale sekcji przekroczą dopuszczalne granice, w celu zachowania bezpieczeństwa powinny być przeprojektowane lub wzmocnione. Do analizy naprężeń w elementach sekcji dla różnych sposobów podparcia oraz wartości przeciążeń wykorzystano metody numeryczne $\mathrm{z}$ wykorzystaniem programu ANSYS [16]. Przedmiotem analizy jest sekcja zmechanizowanej obudowy ścianowej typu ZRP-15/35-POz. Wyniki w postaci map naprężeń zostaną wykorzystane przez projektantów podczas modernizacji sekcji, jak również przy opracowaniu opinii upodatnienia sekcji.

\section{PRZEDMIOT ANALIZY - SEKCJA ZMECHANIZOWANEJ OBUDOWY ŚCIANOWEJ TYPU ZRP-15/35-POZ}

Zmechanizowana obudowa ścianowa typu ZRP-15/35-POz zaprojektowana została w biurze konstrukcyjnym ZRP Bieruń i jest produkowana przez zakład ZRP, jak również inne firmy na zlecenie PGG S.A. Uzupełnieniem dokumentacji są rysunki sekcji 2D wykonane w programie CAD, z możliwością ich wykorzystania do dalszych analiz numerycznych. Rysunek poglądowy sekcji oraz podstawowe parametry techniczne przedstawiono poniżej na rysunku 2 .

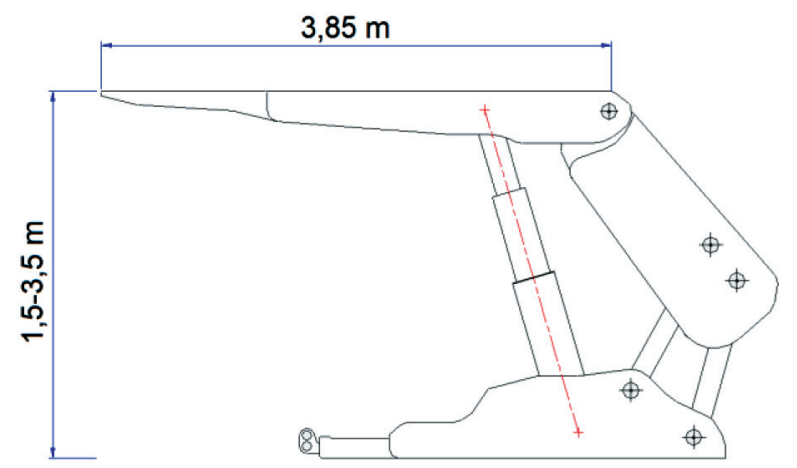

\begin{tabular}{|l|l|}
\hline \multicolumn{2}{|c|}{ Dane geometryczne i podpornościowe } \\
\hline $\begin{array}{l}\text { Zakres wysokości obudowy } \\
\text { geometryczny/roboczy }\end{array}$ & $1,5-3,5 \mathrm{~m} / 1,7-3,4 \mathrm{~m}$ \\
\hline Krok sekcji & $0,8 \mathrm{~m}$ \\
\hline Długość stropnicy & $3,85 \mathrm{~m}$ \\
\hline Typ & $\begin{array}{l}\text { podporowo-osłonowa } \\
\text { dwustojakowa }\end{array}$ \\
\hline Liczba stojaków & 2 \\
\hline Średnice stojaka I st. / II st. & $\varnothing 0,30 / 0,23 \mathrm{~m}$ \\
\hline Podporność wstępna stojaka & $1,767-2,121 \mathrm{MN}$ \\
\hline Podporność robocza stojaka & $3,039 \mathrm{MN}$ \\
\hline Ciśnienie zasilania & $25-30 \mathrm{MPa}$ \\
\hline Ciśnienie robocze & $43 \mathrm{MPa}$ \\
\hline $\begin{array}{l}\text { Przyłącze stojakowe i zabezpie- } \\
\text { czenie przed przeciążeniami }\end{array}$ & typ ZRP II \\
\hline
\end{tabular}

Rys. 2. Rysunek pogladowy oraz podstawowe dane techniczne sekcji zmechanizowanej obudowy typu ZRP-15/35-POz

Zaprojektowana sekcja ZRP-15/35-POz mieści się w realizowanym programie zakładu ZRP-Bieruń związanym z unifikacją i normalizacją obudów dla potrzeb PGG S.A. 


\section{PRZYGOTOWANIE MODELU ORAZ JEGO WARUNKI BRZEGOWE}

Wykorzystując rysunki importowane z programu CAD, zbudowano model 3D odwzorowujący postać konstrukcyjną sekcji obudowy pod względem geometrii całego układu. Na rysunku 3 przedstawiony został stworzony model 3D sekcji zmechanizowanej obudowy ZRP-15/35-POz wykorzystany do dalszych analiz.

Obliczenia kinetostatyczne modelu wykonano programem PrsLab 1.4.5 [17], natomiast wytrzymałościowym programem ANSYS [16]. Do analiz przyjęto materiał izotropowy o liniowej charakterystyce odkształceniowej. Parametry materiału przyjęto jak dla stali konstrukcyjnej tj. moduł Younga $E=200 \mathrm{GPa}$ i współczynnik Poissona $v=0,3$. Jako kryterium wytrzymałościowe przyjęto minimalną granicę plastyczności stali gatunek S690QL, tj. $R e=690 \mathrm{MPa}$. Siatka i liczba elementów została wygenerowana przez program ANSYS. Wykonano obliczenia numeryczne dla obciążeń elementów sekcji zgodnie z normą

a)
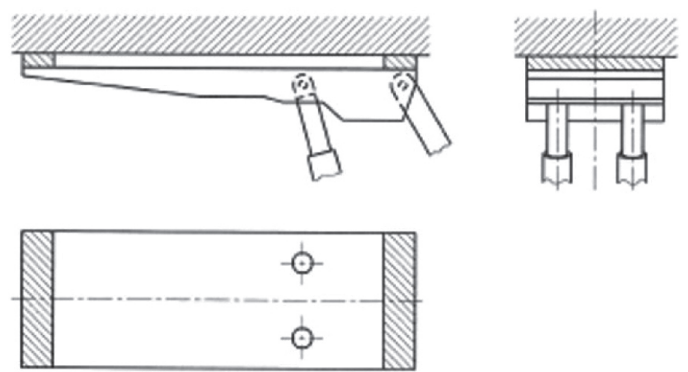

b)
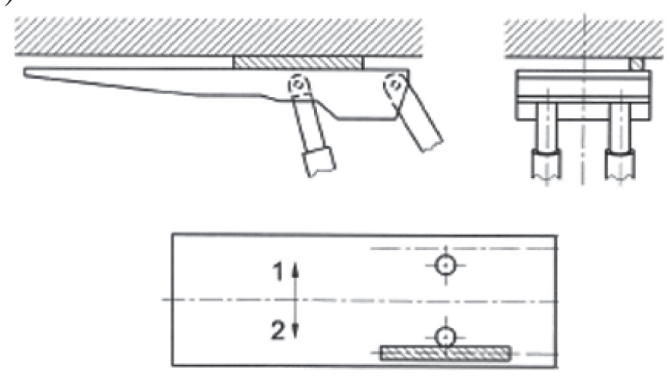

c)
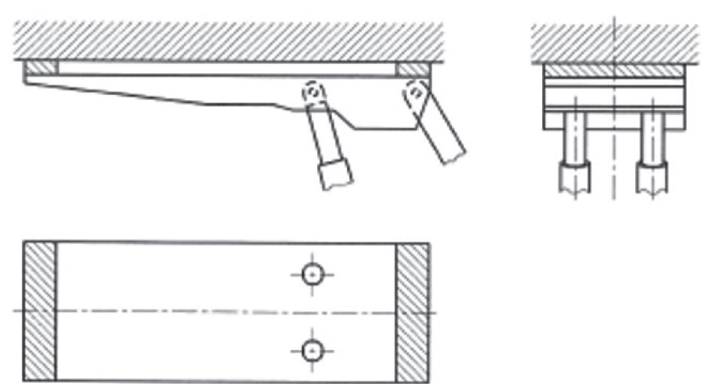

Rys. 4. Analizowane sposoby podparcia sekcji: a) symetria; b) asymetria boku stropnicy; c) asymetria po przekątnej spagnicy $w$ obliczeniach numerycznych
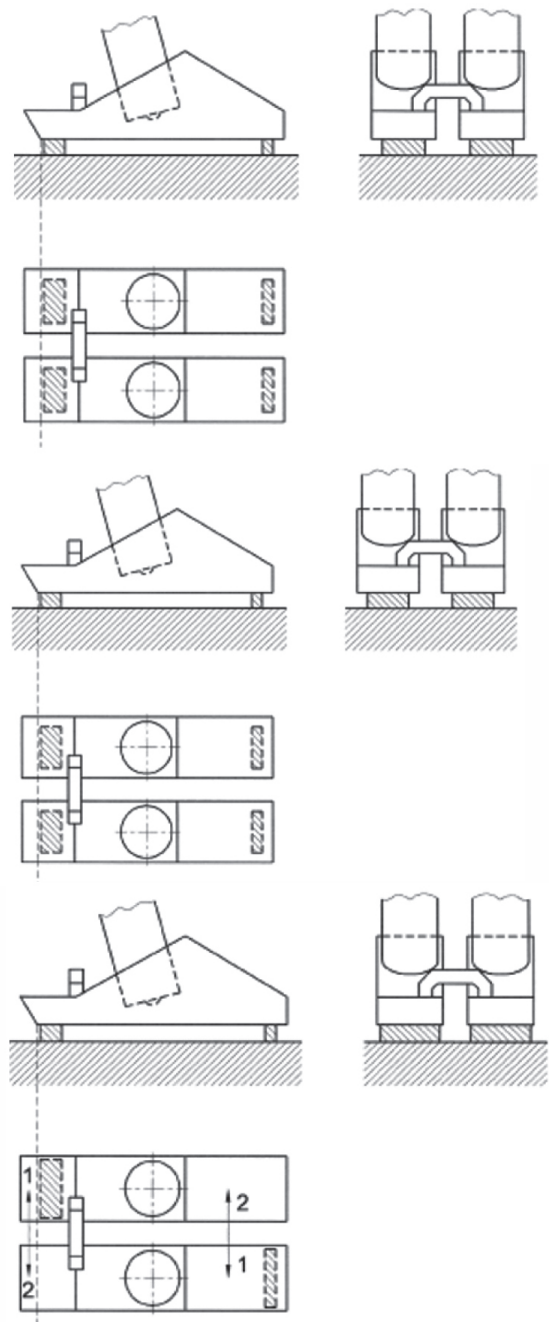

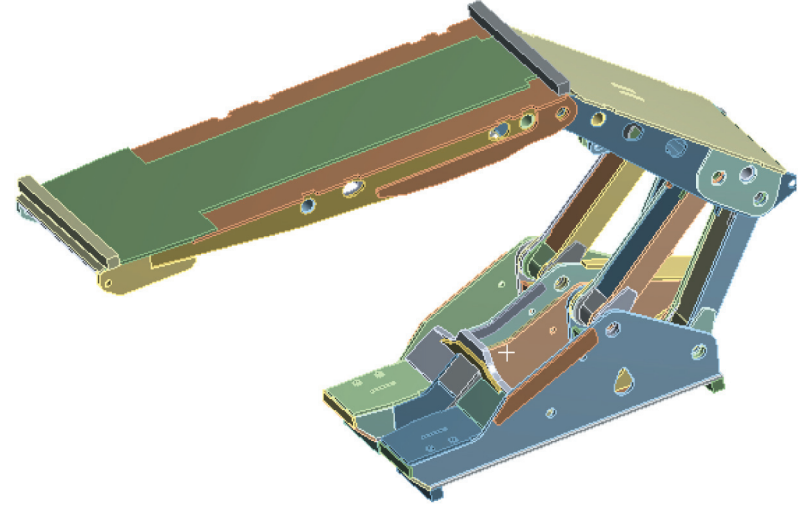

Rys. 3. Model przestrzenny sekcji zmechanizowanej obudowy ścianowej ZRP-15/35-POz wykorzystany

PN-EN 1804-1+A1:2011 [4] i przyjęto współczynniki przeciążenia 1,05 dla obciążeń niesymetrycznych oraz 1,2 dla obciążeń symetrycznych. Dodatkowo dla obciążeń symetrycznych i asymetrycznych przyjęto współczynnik przeciążenia 2,0 zgodnie z metodą GIG dotyczącą upodatnienia sekcji obudowy [11, 12]. Przedmiotem analiz była sekcja podparta zgodnie z rysunkiem 4 . 
Analizę numeryczną przeprowadzono dla wybranych trzech sposobów podparcia i dla wysokości roboczej sekcji ZRP, dla której występują największe naprężenia w materiale elementów.

\section{OBLICZENIA NUMERYCZNE OBUDOWY ZMECHANIZOWANEJ}

Wyniki przeprowadzonych symulacji numerycznych przedstawiono w postaci barwnych map naprężeń zredukowanych w poszczególnych elementach sekcji. Symulacje przeprowadzono oddzielnie dla podstawowych elementów sekcji (stropnica, spągnica) oraz złożeniowo dla sekcji. W publikacji omówiono jedynie mapy złożone naprężeń zredukowanych, które w wystarczający sposób przedstawiają wyniki przeprowadzonych analiz numerycznych. Analizy zostały przeprowadzone dla wartości przeciążeń wynikających z polskiej normy dla różnych sposobów podparcia sekcji $(1,05$ i 1,2$)$ oraz przypadku przeciążenia wynikającego z warunku upodatnienia $(2,0)$ jako pochodna wstrząsu górotworu. Mapy naprężeń zredukowanych w sekcji i jej elementach dla różnych sposobów podparcia i współczynników przeciążenia pokazano na rysunkach 5-10.
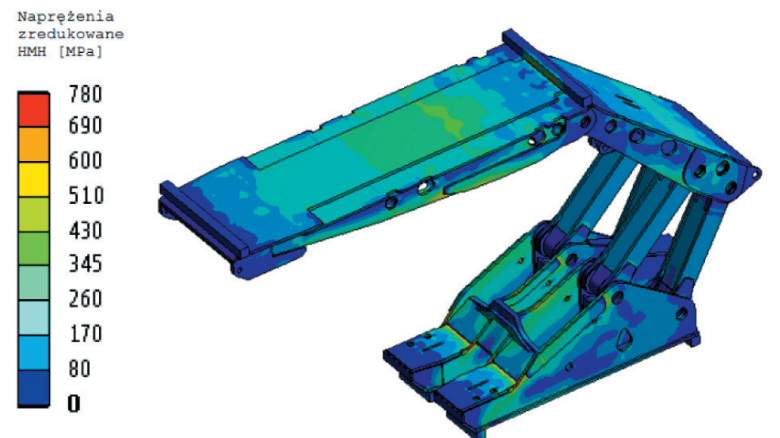

Współczynnik przeciążenia 1,2

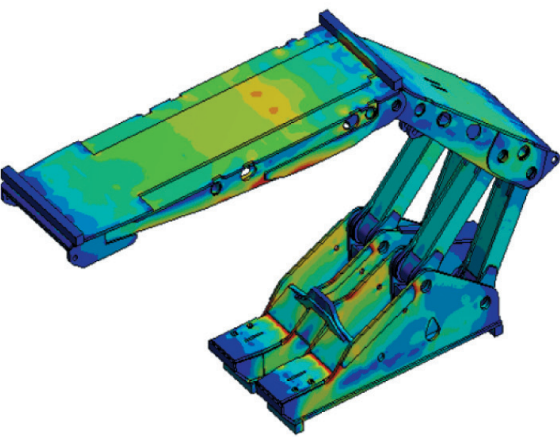

Współczynnik przeciążenia 2,0

Rys. 5. Mapy naprężeń zredukowanych w sekcji przy podparciu symetrycznym wedtug rysunku $4 a$

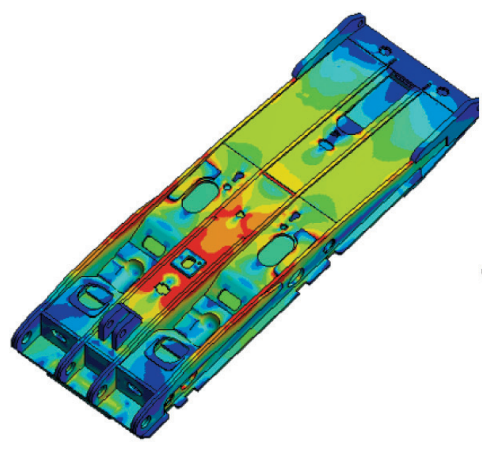

stropnica

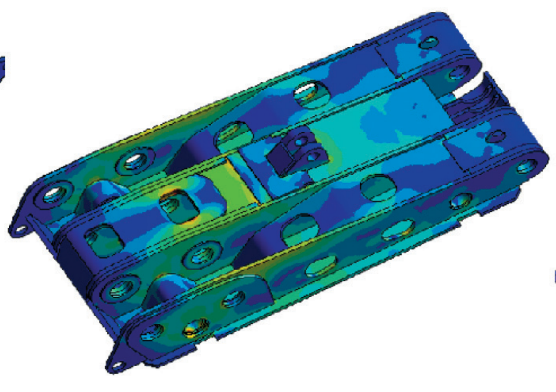

osłona odzawałowa

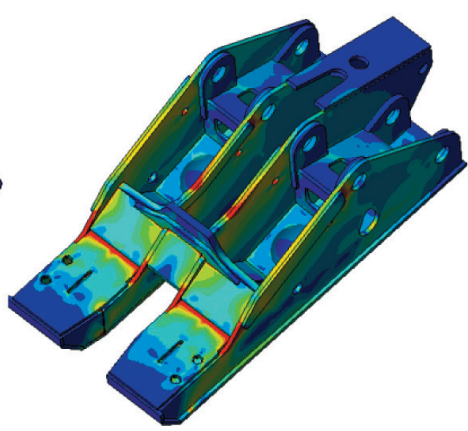

spągnica

Dla współczynnika przeciążenia 2,0

Rys. 6. Mapy naprężeń zredukowanych w elementach sekcji przy podparciu symetrycznym wedtug rysunku $4 a$

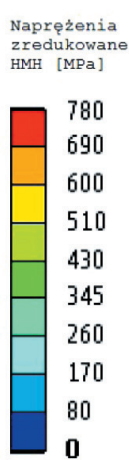

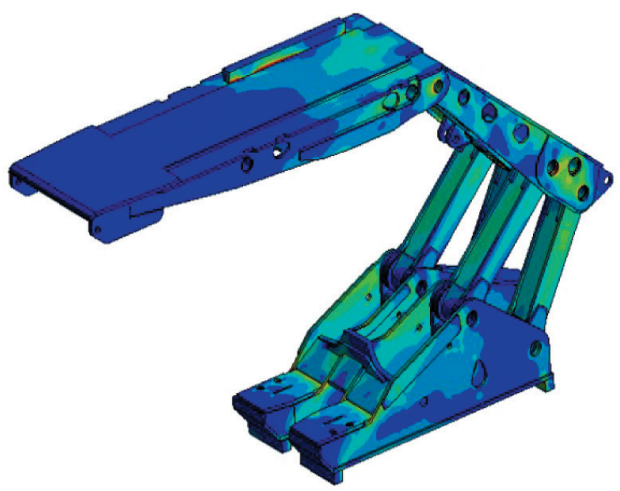

Współczynnik przeciążenia 1,05

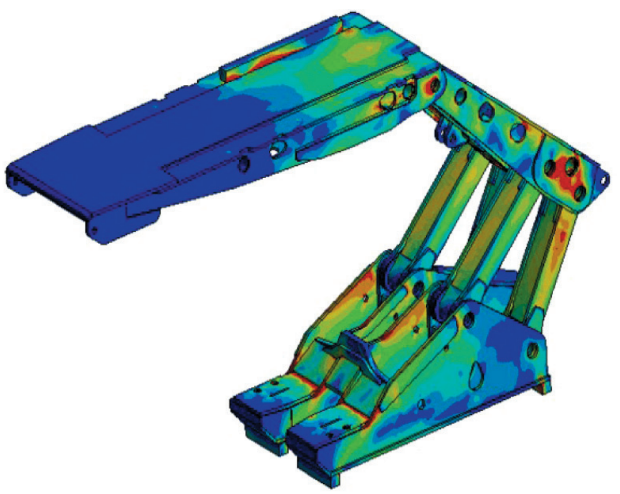

Współczynnik przeciążenia 2,0

Rys. 7. Mapy naprężeń zredukowanych $w$ sekcji przy asymetrycznym podparciu stropnicy wedtug rysunku $4 b$ 


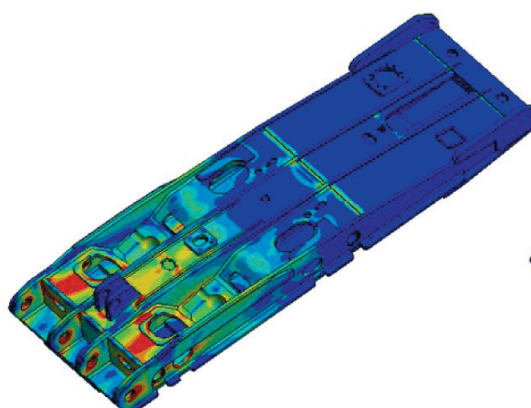

stropnica

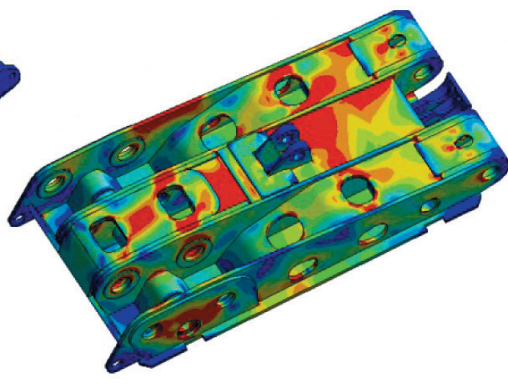

osłona odzawałowa

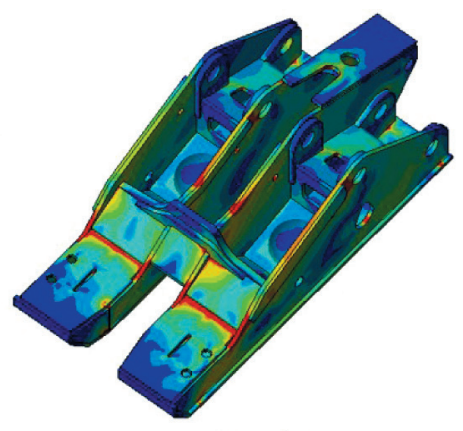

spagnica

Dla współczynnika przeciążenia 2,0

Rys. 8. Mapy naprężeń zredukowanych w elementach sekcji przy asymetrycznym podparciu stropnicy wedtug rysunku $4 b$
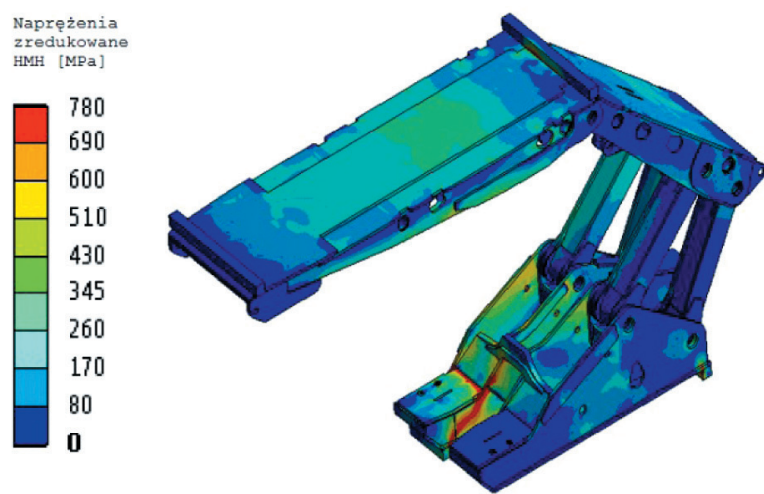

Współczynnik przeciążenia 1,05

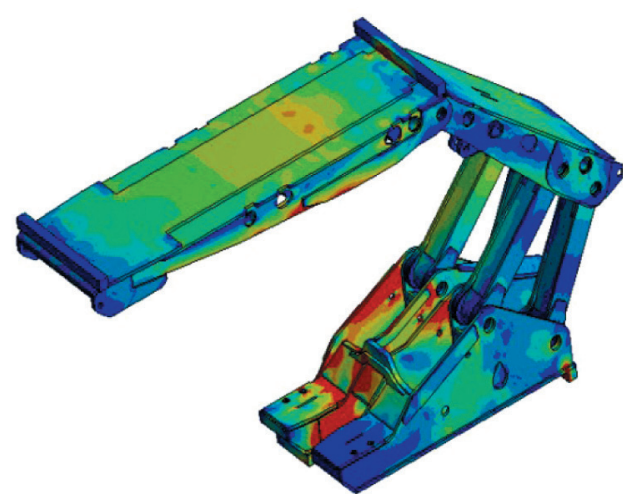

Współczynnik przeciążenia 2,0

Rys. 9. Mapy naprężeń zredukowanych w sekcji przy asymetrii po przekątnej spagnicy wedtug rysunku $4 c$

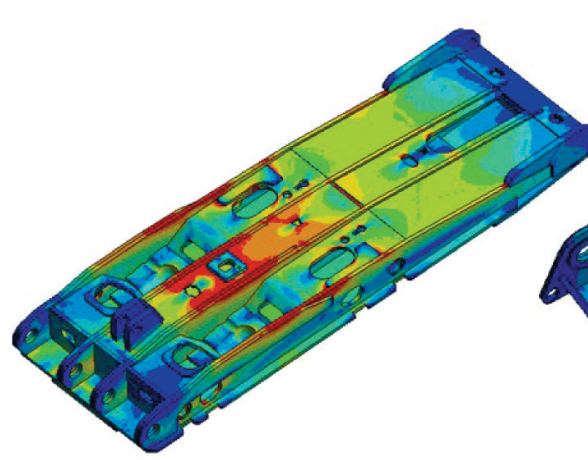

stropnica

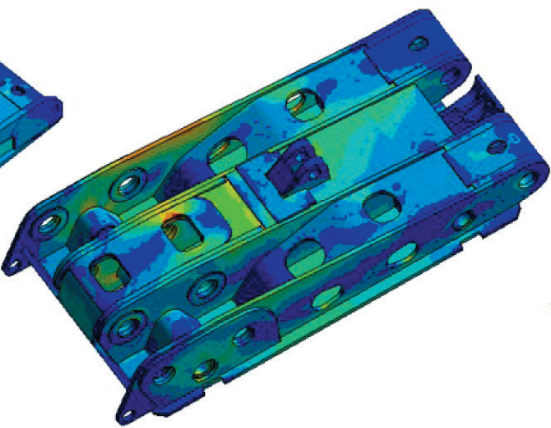

osłona odzawałowa

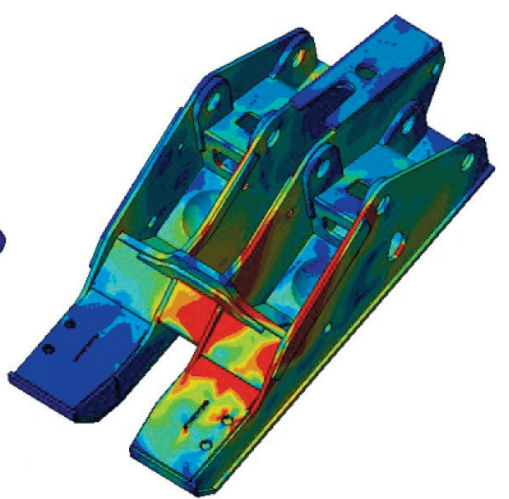

spągnica

Dla współczynnika przeciążenia 2,0

Rys. 10. Mapy naprężeń zredukowanych w elementach sekcji przy asymetrii po przekatnej spagnicy wedtug rysunku 4c

\section{PODSUMOWANE I WNIOSKI}

Przedstawiona w niniejszym artykule problematyka dotyczy niezwykle ważnego zagadnienia dla bezpieczeństwa eksploatacji w ścianie $\mathrm{z}$ uwagi na to, że aktualnie ponad $60 \%$ wydobycia odbywa się w pokładach zagrożonych wstrząsami górotworu. Wskutek występowania wstrząsów górotworu następuje przeciążenie konstrukcji sekcji obudowy zmechanizowanej znacznie powyżej wymaganych polskimi normami współczynników $(1,05$ i 1,2) [2, 5, 6, 11]. Występuje również możliwość dużej asymetrii rozkładu obciążenia na obudowie, co dodatkowo pogarsza warunki pracy sekcji. Dlatego właśnie autorzy publikacji zdecydowali się na obciążenie sekcji obudowy z dwukrotnym przeciążeniem, aby uzyskać informację co do zakresu i miejsca w konstrukcji występowania zwiększonych przeciążeń (na rysunkach 5-10 kolor czerwony). Jak pokazano na rysunku 6 przy obciążeniu symetrycznym największe przeciążenia występują w stropnicy sekcji. 
W przypadku asymetrycznego podparcia stropnicy największe przeciążenia występują w osłonie odzawałowej (rys. 8). Natomiast w przypadku asymetrii po przekątnej spągnicy najbardziej przeciążone są elementy spagnicy i stropnicy, co obrazuje rysunek 10.

Uzyskane informacje odnośnie do przeciążenia poszczególnych elementów sekcji umożliwiają konstruktorowi wzmocnienie tych miejsc w wyniku zmiany wytrzymałości materiału, wzmocnienia ich czy dokonania zmian konstrukcyjnych. Każda taka czynność poprawia bezpieczeństwo pracy, powoduje również wydłużenie bezawaryjnej pracy sekcji obudowy zmechanizowanej. Przeprowadzone analizy numeryczne wskazują również na celowość dokonywania obliczeń numerycznych konstrukcji sekcji z uwagi na duże rozbieżności pomiędzy współczynnikami przeciążenia wymaganymi polskimi normami, a rzeczywiście występującymi przeciążeniami. Przedstawiona procedura postępowania zostanie wprowadzana $\mathrm{w}$ procesie projektowania i produkcji sekcji w ZRP-Bieruń.

\section{Literatura}

[1] Prusek S., Rajwa S., Wrana A., Krzemień A.: Assessment of roof fall risk in longwall coal mines, „International Journal of Mining, Reclamation and Environment” 2016: 1-17.

[2] Świątek J., Stoiński K.: Case Analysis of Damages to Control Hydraulics of the Leg in the Powered Roof Support Section, IV $^{\text {th }}$ International Innovative Mining Symposium, E3S Web Conf. Vol. 105, 2019, DOI: https://doi.org/10.1051/e3sconf/ 201910503013.

[3] Dyrektywa 2006/42/WE Parlamentu Europejskiego i Rady $z$ dnia 17 maja $2006 r$. w sprawie maszyn, zmieniajaca dyrektywe 95/16/WE, Dziennik Urzędowy Unii Europejskiej L157/24.

[4] PN-EN 1804-1+A1:2011: Maszyny dla górnictwa podziemnego - Wymagania bezpieczeństwa dla obudowy zmechanizowanej-Część 1: Sekcje obudowy i wymagania ogólne.

[5] PN-EN 1804-2+A1:2012: Maszyny dla górnictwa podziemnego - Wymagania bezpieczeństwa dla obudowy zmechanizowanej-Część 2: Stojaki i pozostate sitowniki.
[6] PN-EN 1804-3+A1:2012: Maszyny dla górnictwa podziemnego - Wymagania bezpieczeństwa dla obudowy zmechanizowanej-Część 3: Hydrauliczne układy sterowania.

[7] Rozporzadzenie Ministra Energii z dnia 23 listopada $2016 r$. w sprawie szczegółowych wymagań dotyczacych prowadzenia ruchu podziemnych zakładów górniczych, Dz.U. z 2017 r., poz. 1118.

[8] Prusek S., Rajwa S., Walentek A., Masny W.: Powered support selection for longwall workings in dynamic load conditions, „3rd International Symposium on Mine Safety Science and Engineering, Montreal" 2016: 13-19.

[9] Rajwa S., Masny W., Wrana A.: A comprehensive method for the selection of powered roof support in conditions of the rockburst hazard, „Wiadomości Górnicze” 2017, 1: 2-7.

[10] Rajwa S., Prusek S., Stoiński K.: Opis metody upodatnienia zmechanizowanej obudowy ścianowej, „Bezpieczeństwo Pracy i Ochrona Środowiska w Górnictwie” 2016, 12: 3-8.

[11] Stoiński K.: Obudowy górnicze w warunkach zagrożenia wstrzasami górotworu, Wydawnictwo GIG, Katowice 2000.

[12] Stoiński K.: Metoda upodatnienia sekcji zmechanizowanych obudów ścianowych, Praca statutowa GIG, nr 10001103-150, GIG, Katowice 2006 [niepublikowane].

[13] Przemyk A., Harlecki A., Tengler S.: Metoda obliczania wytrzymatości ram samochodów ciężarowych, „Autobusy” 2017, 12: 1252-1257.

[14] Dębski H., Koszałka G., Ferdynus M.: Wykorzystanie MES $w$ analizie struktury nośnej ramy naczepy o zmiennych parametrach eksploatacyjnych, „Eksploatacja i Niezawodność” 2012, 14, 2: 107-113.

[15] Osmęda A.: Porównanie wyników analiz numerycznych i prób wytrzymałościowych demonstratora struktury lotniczej, „Prace Instytutu Lotnictwa" 2016, 3, 244: 123-134.

[16] ANSYS V16, 2015.

[17] PrsLab 1.4.5, program autorski PGG S.A., Oddział ZRP.

dr inż. JANINA ŚWIĄTEK prof. dr hab. inż. KAZIMIERZ STOIŃSKI Główny Instytut Górnictwa pl. Gwarków 1, 40-166 Katowice \{jswiatek, kstoinski\}@gig.eu mgr inż. KONRAD STYRYLSKI PGG S.A. Zakład Remontowo-Produkcyjny ul. Granitowa 132, 43-155 Bieruń konrad.styrylski@gmail.com 